\title{
Quantifying the Impact of Green-Roofs on Urban Heat Island Mitigation
}

\author{
Sara Sahnoune and Nassira Benhassine
}

\begin{abstract}
Climate change is one of the main concerns of our times, and it became even more noticeable due to its impact on global temperature, precipitation patterns, and even arctic sea ice melting. Moreover, it has been proven that climate change is one of the main factors affecting the Urban Heat Island (UHI); which in its turn, increases the energy demand in sustainable cities, where reducing power costs still a major challenge. Furthermore, in order to keep a balanced environment, and contribute to temperature mitigation, the use of vegetation cover is definitely one remarkable strategy. It helps decreasing the temperature down to the values required in sustainable development, reducing energy consumption, and lowering Greenhouse Emission (GHE). In this work, we assess the impact of green-roofs on UHI, and we try to define a decision model that helps calculating the best green-roof/green-infrastructure ratio. Besides, we aim to identify the best practices and measures to take in order to mitigate the UHI in semi-arid climate areas.

Our work involves the use of a Geographic Information System (GIS), which provides a support to estimate the greenery conditions. Our methodology is based on a probabilistic and comparative approach, and evaluated using different green-roof models. We select a residential area in Constantine, Algeria as our study subject, and we use ENVI-met as the software support. Among the findings of this study, providing proper, yet experimentally proven recommendations on how, how much and where to use green roofs, was our main contribution. In addition, the results of our study indicate not only the impact of green-roofs on UHI, but also the effect of large-scale green-roof installation on the liveable areas in sustainable cities.
\end{abstract}

Index Terms-Climate change, geographic information system, green-roofs, sustainable development, urban heat island.

\section{INTRODUCTION}

A city or a metropolitan area, which is warmer than its surrounding rural areas, is called an Urban Heat Island (UHI). The phenomenon was first studied by Howard [1], [2], who has noticed a significant difference in nocturnal temperatures between the UHI and its surroundings. This climate change is noticed by the difference in the frequency and intensity of heat waves as well [3]. In other words, the UHI phenomenon occurs in a city when the natural land cover, such as vegetation areas, is replaced with dense concentrations of pavement, buildings, and other surfaces that absorb and retain heat [4], [5]. Some of the effects related with the UHI presence are the deterioration of living environment; the expansion of energy demand [6]-[11]; the increase of air

Manuscript received July 4, 2016; revised August 31, 2016.

The authors are with Laboratory Bioclimatic Architecture and Environment, Faculty of Architecture and Urban Planning, University of Constantine 3, Algeria (e-mail: sarah.sahnoune@gmail.com, farah.alg@hotmail.com). pollution levels [12]-[15], the impact on stress among the residents [16], [17] and the risk of heat-related morbidity and mortality [17]-[19]. The UHI phenomenon has been extensively studied [20]-[23] and it became a necessary part for urban sustainability planning. For this and other reasons, adaptation and mitigation strategies are critical steps to reduce UHIs and their subsequent adverse environmental effects [24].

According to numerous works, the interaction between the urban ecosystems and the global climate system suggests a strong relation between sustainability and climate change [25], [26]. Consequently, many sustainable practices have been adopted as solutions to tackle this issue, and keep a balanced living environment, on the one hand; and to contribute in temperature mitigation, and provide sufficient energy, on the other hand [27]. Thought, the use of vegetation cover is definitely one remarkable strategy.

The adaptation of an Urban Green Infrastructure (UGI) significantly contributes in decreasing the city temperature, and has an important reduction potential on the UHI effect as the UGI provides climate regulating effects like evapotranspiration and shading [28], [29]. In a related work, Wong and Chen [30] declared that greenery in a built environment could affect all the aspects of the urban life such as the environment, the economic, the aesthetic and the social aspect. Thus, increasing the green areas is an important ecological measure to combat UHI effects and equalize local temperatures [31]. Since transforming residual spaces into green areas still a huge challenge in densely urbanized areas, turning traditional bitumen flat roofs into green ones could be the best solution. The building roofs include a noticeable percentage of the urban area and participate extremely to the intensification of UHI, almost 20 to $25 \%$ of the urban surface [32]. Besides, they represent an important component of the buildings when it comes sustainable outputs [33].

Berardi et al present a comprehensive review of the environmental benefits of green roofs [34]. They discussed in their work how to reduce heating and cooling loads of buildings, mitigate storm water run-off, and improve air quality in cities [35]-[39]. A number of recent studies have discussed the performance of vegetated roofs under different climate conditions [40]-[47] and for different types of roof insulations too [48]. Both vegetation and green-roofs have proven their efficiency on mitigating the UHI.

Our work is mainly led by the above facts and other problematic questions. What is required contribution of the green roof in an UHI that returns noticeable results? Are these results reducing air temperature and mitigating UHI only? What is the best green-roof/green-infrastructure ratio that returns good results and minimize setting up costs? We 
address in this experimental study the impact of green roofs on the UHI by exploring the above and other questions, and defining a decision model that helps calculating setting up green areas in a sustainable city.

\section{Methodology}

In order to study the impact of green-roofs on the UHI, and define a decision model that helps calculating the best green-roof/green-infrastructure ratio, we conducted an experimental study in a semi-arid area. We have mainly used measurement instruments to gather on-site temperatures, and data from the local weather-station.

The main analysis tool used in this study was a Geographic Information System (GIS) called ArcGIS ${ }^{1}$. Our choice was conducted by its effective way of converting complex measurement data in simple charts and graphics that can be easily readable by decision maker or general public [49]. Moreover, its numerous options, when it comes to three-dimensional calculations, was one of its numerous features. We have used ArcGIS to estimate the greenery conditions in the study area, and to define the optimal urban situation regarding the built mineral surfaces, and natural surfaces. In order to calculate the contribution of flat roofs in regulating the imbalance, expressed in ratios, between mineral and natural surfaces, and to replace the leak of natural areas; we used a probabilistic and comparative approach, which was evaluated using different green-roof models. In fact, at this step of the study, we used ENVI-met $4.0^{2}$, which provides many simulation features and models. The data used in both steps was collected in early June 2016, and was mainly composed of climate monitoring and plant distribution data.

\section{A. Case Study}

Constantine is located in north-eastern Algeria at $36^{\circ} 17^{\prime} \mathrm{N}$ latitude and $6^{\circ} 37^{\prime} \mathrm{E}$ longitude and $574 \mathrm{~m}$ above the sea level. The total area of the city is $2,187 \mathrm{~km}^{2}$ with a population of 943,112 , and a density of $430 / \mathrm{km}^{2}$. It is characterized by a semi-arid climate with relatively hot and dry season that goes from June to September and a cool season from October until March. As for average temperatures, $29.2{ }^{\circ} \mathrm{C}$ is average in July, the hottest month, and $7.6^{\circ} \mathrm{C}$ is the average temperature in January. The average precipitation is about $531.6 \mathrm{~mm}$ and the average humidity is $53.13 \%$. It has a very important annual insolation from an average of $253,54 \mathrm{~h}$ with minimal $154,4 \mathrm{~h}$ recorded in December and a maximum of $379,6 \mathrm{~h}$ recorded in July; these values suggest that the intensity of global radiation decreases during the cold and wet period, and increases during the hot dry period. This latter, requires a sustainable urban design, where summer cooling is one of its priorities.

A residential area of Constantine was selected as a case study area as shown in (Fig. 1.) Its dimensions are: width 547 $\mathrm{m}$ (left-right) and length $206 \mathrm{~m}$. The chosen area shows a good presence of vegetation and certainly flat and bitumen roofs. It is built on a plot of 15 ha with a density of 69 units /

${ }^{1}$ https://www.arcgis.com/features/index.html ${ }^{2}$ http://www.envi-met.com/ ha. The building was realized with a reinforced concrete.

\section{B. Quantifying Greenery Conditions}

Using ArcGIS, we extracted the different area types, such as the natural area (vegetation), the canopy area, the building area and the pavement area. Shape-files for these four areas were made according to data provided by the office of Plan Development and Urban Planning (PDAU) in the city, and other aerial images (Google-Earth).

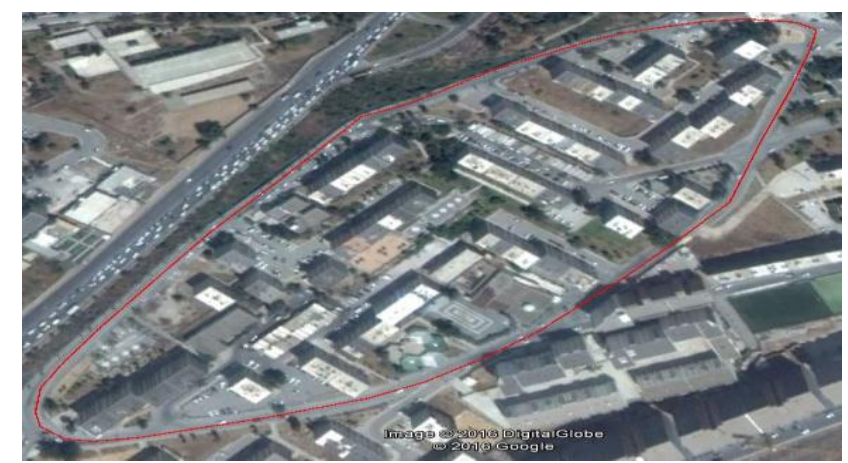

Fig. 1. Aerial image of the site for the case-study (google-eath pro2016).

Besides, an additional site data was collected using in-field measurement instruments. The areas were calculated from the attribute table of each layer in square meter $\left(\mathrm{m}^{2}\right)$ then they are converted to percentage portions (\%).

In order to quantify and qualify the environmental contribution of vegetated flat roofs in regulate the temperatures of cities four scenarios were evaluated to find the best green-roof/ green-infrastructures ratio. We set in each scenario a fixed portion of green-roofs out of the entire flat-roof surface. The used portions are $100 \%, 75 \%, 50 \%$ and $25 \%$. In order to evaluate the greenery condition, the changes of green rate were identified in each scenario.

\section{Measurements}

The ambient temperatures, the relative humidity (\%) and the wind speed $(\mathrm{m} / \mathrm{s})$ were considered using a multi model unit LM -8000. The examination took place during a hot and clear day (June 3rd, 2016) for 14 hours from sunrise to sunset and the measures were taken every hour at a $2.50 \mathrm{~m}$ high level. The results were recorded from two representative measurement points in the site. The first in on open area with a dense vegetation cover (S1), and the second in an area where the vegetation is visibly less that the first (S2).; Both measurement points are illustrated. In addition; the measurements were compared to the reference data gathered from the local weather station of Constantine.

\section{Simulations Approach}

The microclimate modeling software ENVI-met simulates the surface-plant-air interaction in an urban quarter and hence, allows small-scale analyses of climate conditions and urban planning strategies [50]. In this study, ENVI-met simulation was used to predict the ambient temperature in different green-roofs/ green-infrastructure scenarios during the day-time for 14 hours (from 6AM -7PM).

The model has been created with the area input file editor of the ENVI-met as shown on Fig. 2. "(a)" and "(b)" , rotated of $51^{\circ}$ counter clock wise, according to the main direction of development of the buildings. There are 27 buildings in the 
model, many of them having common walls, with a height between 15 and $18 \mathrm{~m}$. For the modeling of the vegetation, two different plant types have been employed:

"T1": tree $10 \mathrm{~m}$ tall, very dense, leafless base; "xx": grass, average density, And $50 \mathrm{~cm}$ tall.

Soil has been modeled with loamy soil for the whole area, with the exception of the main road, covered in asphalt road, and the sidewalks covered by concrete pavement.

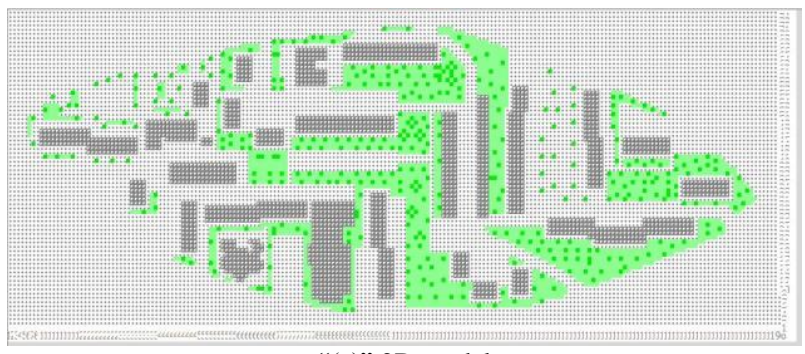

"(a)" 2D model

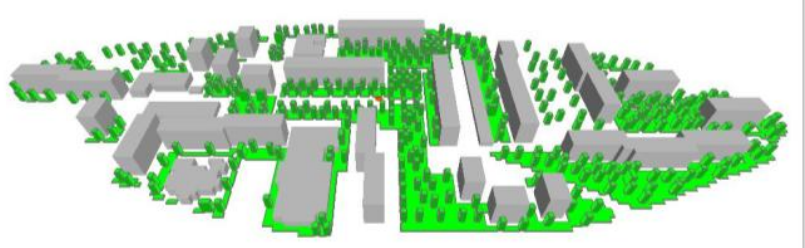

"(b)" 3D model

Fig. 2. Two dimension (a) and three dimension (b) model of the case-study.

We used different scenarios during the simulation, including the base case "(b)" (Fig. 2.) and the green-roofs scenarios "(a)" 100\% Green-Roof, "(b)" $75 \%$ Green-Roof, “(c)" 50\% Green-Roof and “(d)" 25\% Green-Roof were selected (Fig. 3.). An average density of $50 \mathrm{~cm}$ tall grass has been applied to the flat-roofs buildings. The instalaltion of green-roofs was distributed according to the zoning of hot areas calculated from the base-case, and in the of minimizing the cost of installation and maintenance.

We consider different urban form during the scenario configuration such as, location, initial meteorological conditions, vegetation, and building materials. ENVI-met results are shown in air temperature maps. It is important to note that ENVI-met is mainly used to compare the differences between scenarios, not to give absolute information on specific temperatures. The model input information is shown in Table I.

\section{TABLE I: MODEL'S INPUT INFORMATION}

\begin{tabular}{ll}
\multicolumn{2}{c}{ TABLE I: MODEL'S INPUT INFORMATION } \\
\hline Location & Constantine, $36.34^{\circ} \mathrm{N}, 6.60^{\circ} \mathrm{E}$ \\
Simulation time & 14 hours, from $06.00 \mathrm{AM} .03 .06 .2016$ \\
Wind speed & $0.3 \mathrm{~m} / \mathrm{s}$ \\
Wind direction & $51^{\circ}$ to the North \\
Temperature average & $\mathrm{min}=291,05^{\circ} \mathrm{K} ; \max =308,05^{\circ} \mathrm{K}$ \\
Relative humidity & $\min =28,3 \% ; \max =47,15 \%$ \\
Specific humidity & $4,62 \mathrm{~g} / \mathrm{kg}$ \\
Wall/ roof proprieties base-case & Reinforced concrete \\
Wall/ roof proprieties & Reinforced concrete/ Green-roofs \\
green-roof cas & \\
\hline
\end{tabular}

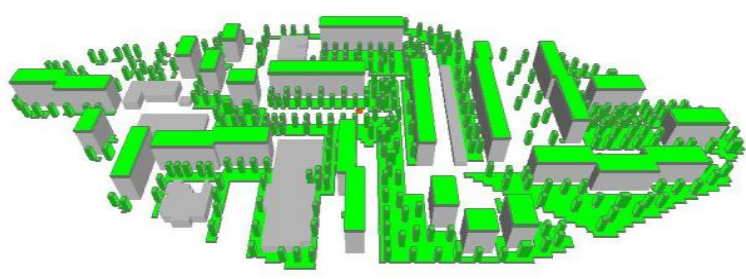

“(a)" $100 \%$ of green-roof

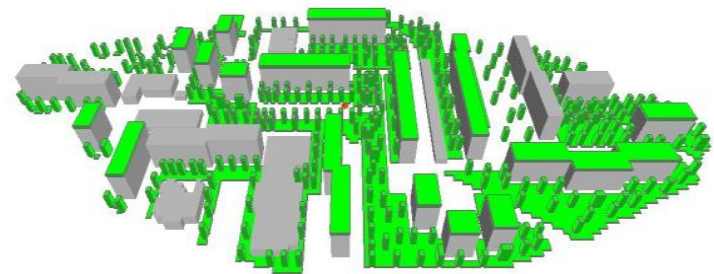

“(b)" $75 \%$ of green-roof

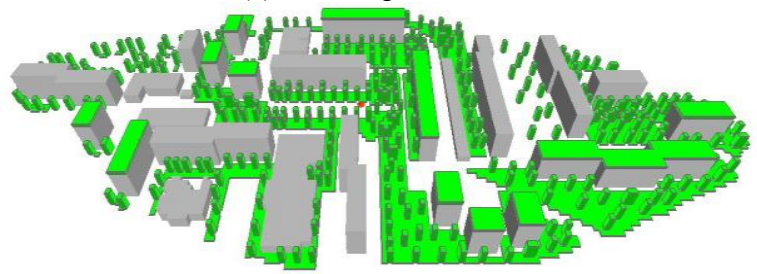

“(c)" $50 \%$ of green-roof

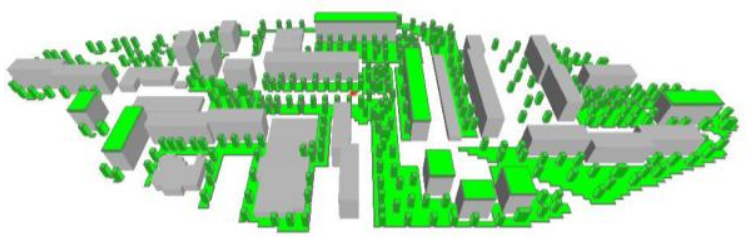

"(d)" $25 \%$ of green-roof

Fig. 3. Different green-roofs scenarios for simulation.

\section{RESULT AND DISCUSSION}

\section{A. Quantifying Greenery Condition Results}

Fig. 4 shows the different layers of the urban area elements in the site.

The total surface area presents $78360 \mathrm{~m}^{2}$, where $31214.13 \mathrm{~m}^{2}$ of it, presents green area, and $15168.05 \mathrm{~m}^{2}$ composes the building area. The total residential rooftop presents $9943.5 \mathrm{~m}^{2}$; the road $32061.7 \mathrm{~m}^{2}$; and the canopy area which covers $3409.79 \mathrm{~m}^{2}$, and overlaps with other surfaces. It's because of this overlapping that the percentages are independent of other values; the calculated result shows the proportion percentage of each area element in Table II.

TABLE II: PERCENTAge AREA LAYERS

\begin{tabular}{ccccccc}
\hline site & $\begin{array}{c}\text { Total } \\
\text { area }\end{array}$ & $\begin{array}{c}\text { Buildings } \\
\text { area }\end{array}$ & $\begin{array}{c}\text { Rooftop } \\
\text { area }\end{array}$ & $\begin{array}{c}\text { Natural } \\
\text { area }\end{array}$ & $\begin{array}{c}\text { Canopies } \\
\text { area }\end{array}$ & $\begin{array}{c}\text { Road } \\
\text { s area }\end{array}$ \\
\hline $100 \%$ & $19 \%$ & $13 \%$ & $49 \%$ & $4 \%$ & $41 \%$ \\
\hline
\end{tabular}

According to these value, we can distinguish the proportion of natural and mineral surfaces, as presented in Table III.

TABLE III: PERCENTAGE MinerAL AND NATURAL AREA

\begin{tabular}{cccc}
\hline site & Total area & Mineral area & Natural area \\
\hline & $100 \%$ & $60 \%$ & $40 \%$ \\
\hline
\end{tabular}

During this analysis, the mineral areas refer to buildings, pavement and roads, and the natural area refers to green spaces and play-area made of a permeable soil, including private gardens, public parks and canopies. In order to evaluate the impact of green-roofs in the site, we have compared it with the base case values. We have calculated the green rate as well, which its values are listed in Table IV. We update the green rate values before each simulation, and according to the related scenario. The results are listed in Table V. 


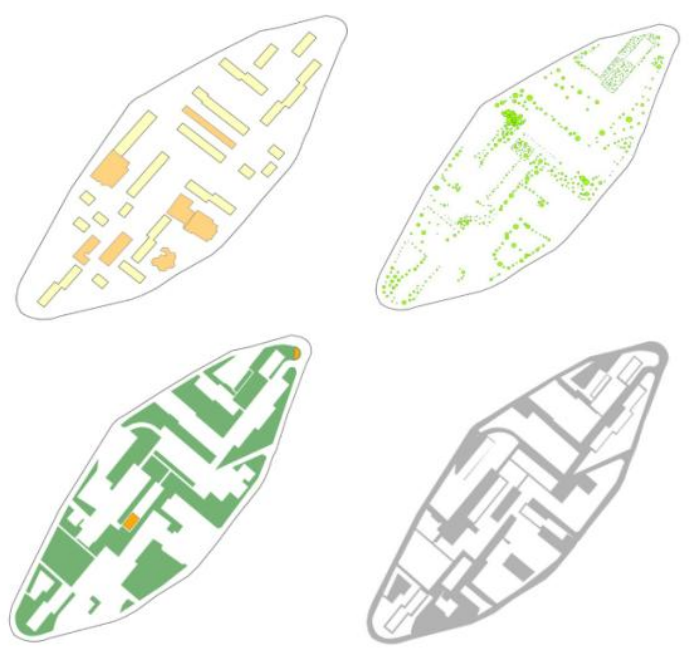

Fig. 4. Different layers area of the site.

\section{B. Measurements Results}

The urban green area mitigates the UHI by lowering the temperature and providing shading. Several studies show that the maximum temperature difference between the inside and outside of the small green area can be $3 \mathrm{~K}$ [51]. Accordingly, we have compared the temperature and the relative humidity of the measuring site between the two measuring points in the site to estimate green-vegetation cover impact on the temperature reduction. The measuring points located at two different places on the site, where the first has more vegetation cover (S1) than the second (S2). We have also compared the temperature and relative humidity of the measuring site and the data of the local weather-station, located at the suburban of Constantine at the study dayas shown in (Fig. 5.) and (Fig. 6.)

TABLE IV: GREEN RATE OF THE SITE

\begin{tabular}{|c|c|c|c|c|c|c|}
\hline \multicolumn{2}{|c|}{$\begin{array}{l}\text { Greenery area } \\
\left(\mathrm{m}^{2}\right)\end{array}$} & \multicolumn{2}{|r|}{$\begin{array}{l}\text { Total site surface area } \\
\qquad\left(\mathrm{m}^{2}\right)\end{array}$} & \multicolumn{3}{|c|}{$\begin{array}{c}\text { Green rate }=(\text { greenery area/total site surface } \\
\text { area }) \%\end{array}$} \\
\hline \multicolumn{2}{|c|}{17506.7} & \multicolumn{2}{|r|}{78360} & \multicolumn{3}{|c|}{22.3} \\
\hline Scenarios & Greenery area $\left(\mathrm{m}^{2}\right)$ & $\begin{array}{c}\% \\
\text { rooftop }\end{array}$ & $\begin{array}{l}\text { Total new greenery } \\
\text { area }(\mathrm{m} 2)\end{array}$ & $\begin{array}{l}\text { Total site surface } \\
\text { area }\left(\mathrm{m}^{2}\right)\end{array}$ & New green rate & $\begin{array}{c}\text { Increase } \\
\text { of green rate }\end{array}$ \\
\hline $100 \%$ & 17506,7 & 13 & 27450.2 & 78360 & 35 & 12.7 \\
\hline $75 \%$ & 17506,7 & 9.5 & 24964.3 & 78360 & 31.8 & 9.5 \\
\hline $50 \%$ & 17506,7 & 6.3 & 22478.4 & 78360 & 28.6 & 6.3 \\
\hline $25 \%$ & 17506,7 & 3.1 & 19992.5 & 78360 & 25.5 & 3.2 \\
\hline
\end{tabular}

The station (S1), under the effect of vegetation cover has registered the lowest average temperature throughout the day, it reaches up to $1.3^{\circ} \mathrm{C}$ difference (the station 1 have more vegetation cover than the station 2 ).

The maximum temperature reaches $34,4^{\circ} \mathrm{C}$ on the station (S1) and $35,4^{\circ} \mathrm{C}$ on the station (S2) respectively at $2 \mathrm{PM}$, while the minimum was $17^{\circ} \mathrm{C}$ on $(\mathrm{S} 1)$ and $18,8^{\circ} \mathrm{C}$ on $(\mathrm{S} 2)$ at 6AM .The recorded values are illustrated in Fig. 5.
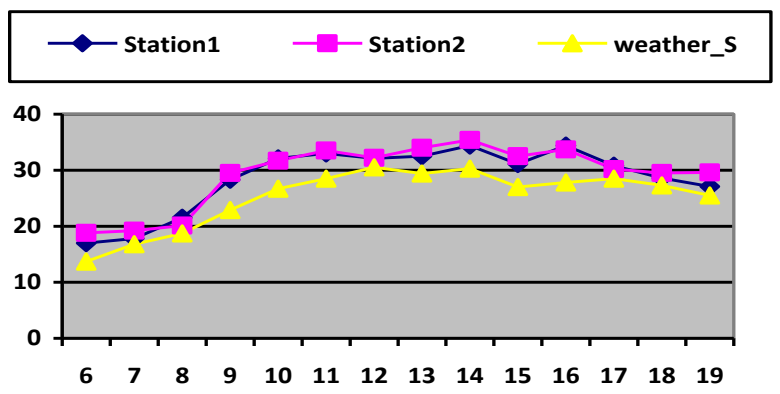

Fig. 5. Air temperature $\left({ }^{\circ} \mathrm{c}\right)$ of the (s1), (s2) and the local weather station.
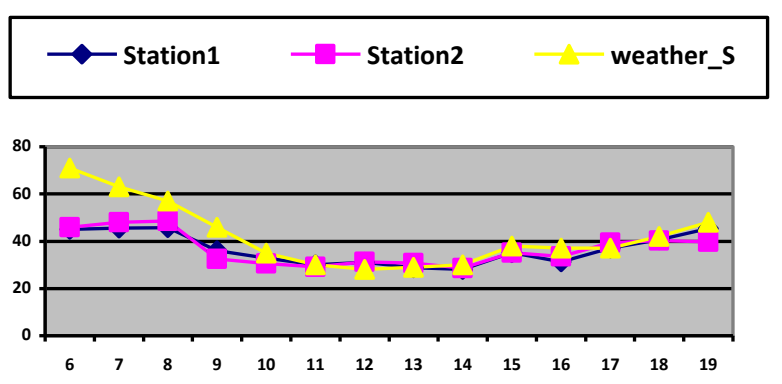

Fig. 6. Relative humidity (\%) of the (s1), (s2) and the local weather-station.

The other parameter we interest in is the relative humidity
(RH). Its evolution during the day is inversely proportional to that of the air temperature; the rate was high in the morning with a maximum of $45.7 \%$ on (S1) and $48,6 \%$ on (S2) respectively at $8 \mathrm{AM}$. Additionally, in the afternoon, the recorded $\mathrm{RH}$ values were clearly lower than the morning values, with a minimum of $28 \%$ on (S1) and $28,6 \%$ on (S2) respectively at $2 \mathrm{PM}$. The recorded values are illustrated in Fig. 6.

By comparing the climatic parameters of measurement stations and weather-station, we have effectively recorded a difference temperature varying each hour (Fig. 5.). The temperature of local weather-station is generally cooler compared to measuring station of the site with a maximum of $30.5^{\circ} \mathrm{C}$ at $12 \mathrm{AM}$ and a minimum of $16.8^{\circ} \mathrm{C}$ at $6 \mathrm{AM}$. The difference of the average annual temperature reaches $2.05^{\circ} \mathrm{C}$ in $\mathrm{S} 1$ and $3.45^{\circ} \mathrm{C}$ in $\mathrm{S} 2$. Accordingly, we note that the values of the RH is higher compared with the measurement points at 6AM to 8AM, and lower after 9AM to the end of the day (Fig. 6.) These last results suggest a significant impact of vegetation cover in lowering air temperature.

\section{Temperature Prediction in Different Scenarios}

The simulation model was performed to predict air temperature, to evaluate the effect of green-roofs scenarios on UHI mitigation, and to define the best green-roofs/greeninfrastructure ratio. The corresponding thermal maps of the studied area were recorded at $2 \mathrm{PM}$ at $2.50 \mathrm{~m}$ ground level. While 2PM is time the when we recorded the highest temperature, $2.50 \mathrm{~m}$ is the height of the pedestal, we used to install the measurement instruments. Air temperature (Ta) of the base-case for the control simulation is illustrated in Fig. 7.

\section{Base-Case}


Simulation analysis reveals a same logic that the results from the measurements. We notice that air temperatures above asphalt pavements are higher than other parts of the area where the maximum reached up to $33.68^{\circ} \mathrm{C}$; a result that was expected due to the low albedo and the lack of shading of pavements by trees in this parts of the site. The lowest surface air temperatures with $31.69^{\circ} \mathrm{C}$ was recorded in locations underneath trees, and vegetation area, a direct consequence of shading the surface and diminution of air temperature.
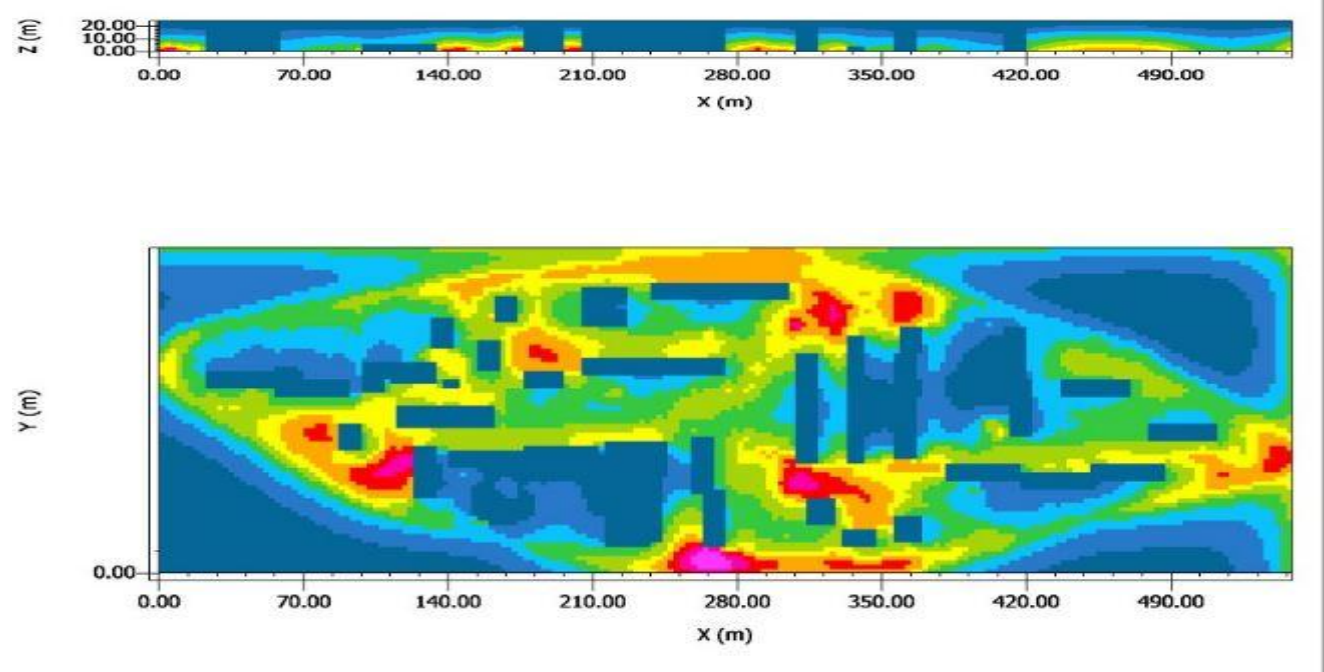

Fig. 7. Ambiant air temperature in "base-case", $x-y$ view at $z=2.50 m$ and $x-z$ view at $y=127.4 \mathrm{~m}$ at $2 \mathrm{pm}$.

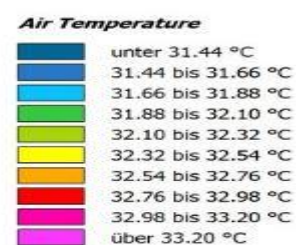

Min: $31.22^{\circ} \mathrm{C}$

Air Temperature

unter $31.89^{\circ} \mathrm{C}$ 31.89 bis $32.09^{\circ} \mathrm{C}$ 32.09 bis $32.29^{\circ} \mathrm{C}$ 32.29 bis $32.49^{\circ} \mathrm{C}$ 32.49 bis $32.69^{\circ} \mathrm{C}$ 32.69 bis $32.88^{\circ} \mathrm{C}$ 32.69 $32.88^{\circ}$ bis $33.08^{\circ} \mathrm{C}$ 33.08 bis $33.28^{\circ} \mathrm{C}$ 33.28 bis $33.48^{\circ} \mathrm{C}$ über $33.48{ }^{\circ} \mathrm{C}$ Min: $31.69^{\circ} \mathrm{C}$

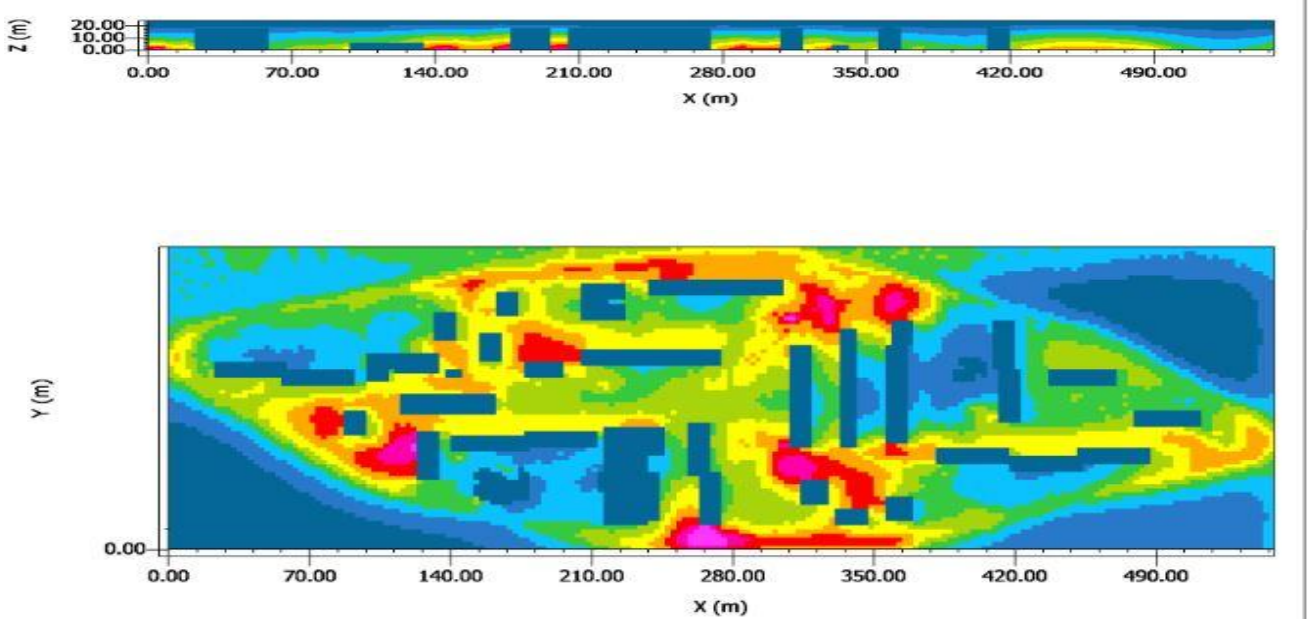

“(a)" scenario $100 \%$ of green-roof
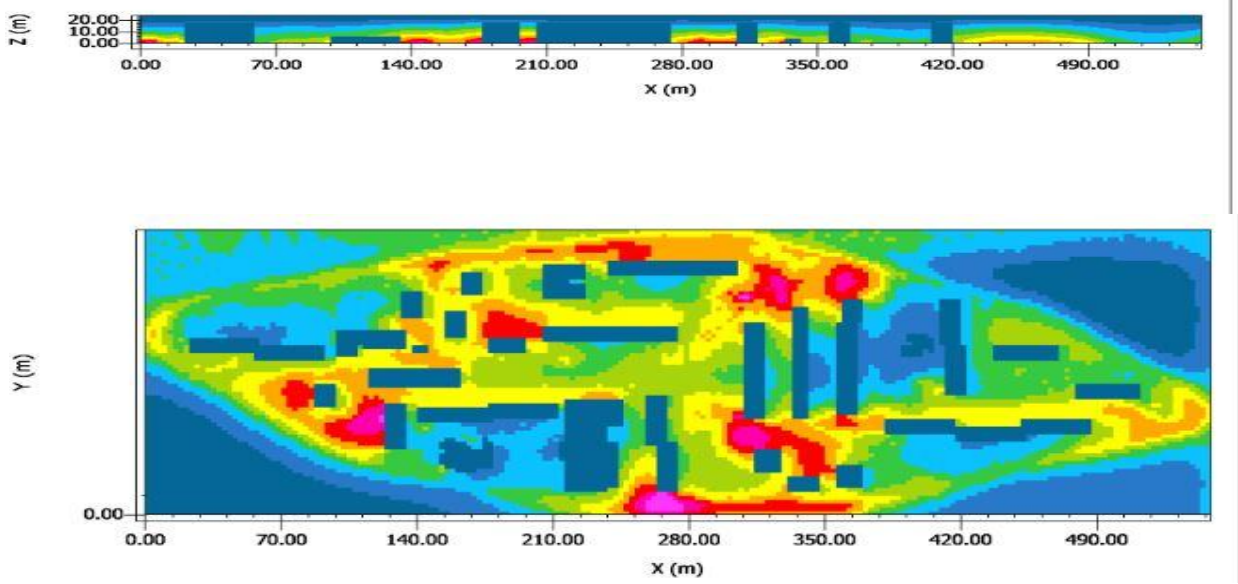

“(b)" scenario $75 \%$ of greeN-ROOF

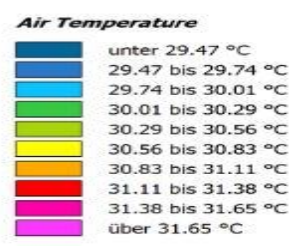

$\operatorname{Min}: 29.19^{\circ} \mathrm{C}$

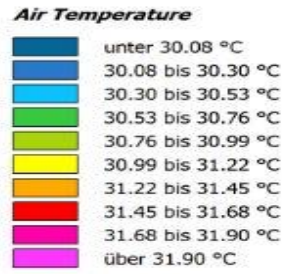

Min: $29.85^{\circ} \mathrm{C}$

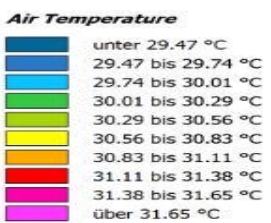

Min: $29.19^{\circ} \mathrm{C}$

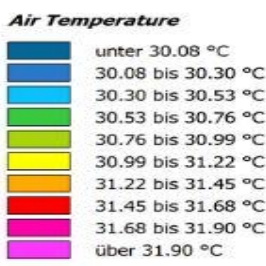

Min: $29.85^{\circ} \mathrm{C}$
Max: $32.13^{\circ} \mathrm{C}$ 


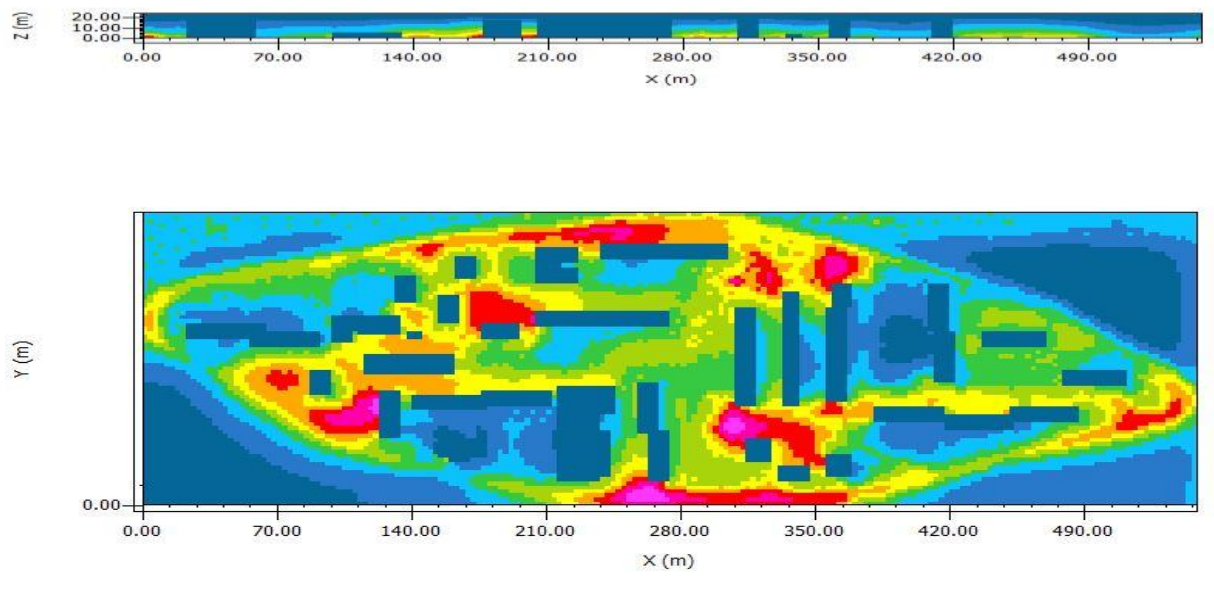

“(c)" SCENARIO 50\% OF GREEN-ROOF
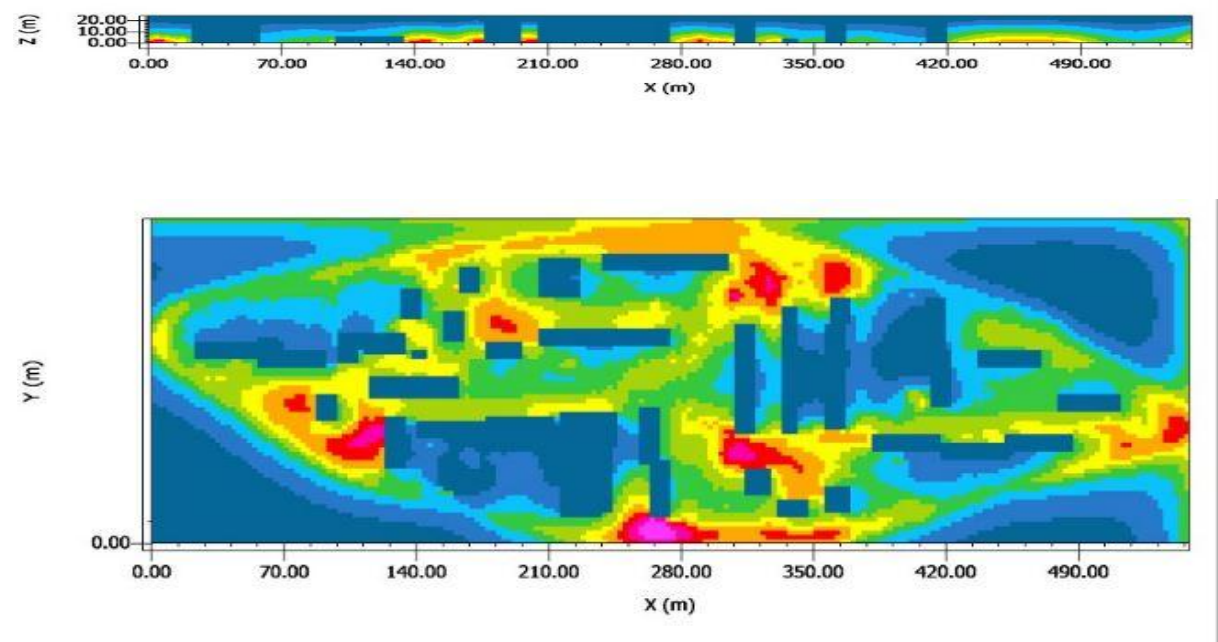

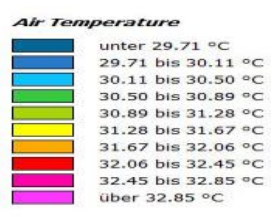

$\operatorname{Min} 220.32 \circ \mathrm{\circ}$

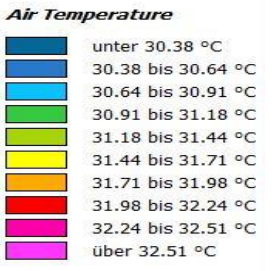

Min: $30.110^{\circ} \mathrm{C}$
Max: $32.788^{\circ} \mathrm{C}$

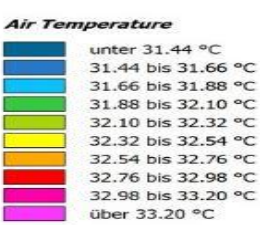

Min: $31.22{ }^{\circ} \mathrm{C}$

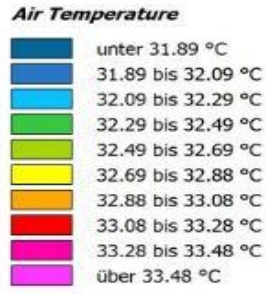

Min: $31.69^{\circ} \mathrm{C}$ Max: $33.68^{\circ} \mathrm{C}$

“(d)" SCENARIO 25\% OF GREEN-ROOF

Fig. 8. Atmospheric temperature in "green-roofs case" sacenarios ("(a)" 100\%, "(b)" 75\%, "(c)" 50\% and "(d)" 25\%), $\mathrm{x}-\mathrm{y}$ view at $\mathrm{z}=2.50 \mathrm{~m}$ and $\mathrm{x}-\mathrm{z}$ view at $\mathrm{y}=$ $127.4 \mathrm{~m}$ at $2 \mathrm{pms}$.

\section{E. Green-Roof Case}

Green-roofs/green-infrastructures scenarios are simulated to have the least impact on air temperature. Hence, cooling effects of GR were defined as the air-temperature differences between the base-case (Fig. 7) and green-roof scenarios ("(a)" $100 \%$, "(b)" $75 \%$, “(c)" $50 \%$ and "(d)" $25 \%$ respectively) presented in Fig. 8. In general, the scenarios "(a)" 100\% and "(b)" $75 \%$ of green-roofs decreased the ambient air temperature by $1.69^{\circ} \mathrm{C}$ in average above $2.5 \mathrm{~m}$ ground level, while the maximum temperature decrease was close to $1.55^{\circ} \mathrm{C}$ and the minimum close to $1.84^{\circ} \mathrm{C}$.

In the scenario of "(c)" $50 \%$ GR, the ambient air temperature decreased by $1.29^{\circ} \mathrm{C}$ in average, while the maximum temperature decrease was close to $0.9^{\circ} \mathrm{C}$ and the minimum close to $1.55^{\circ} \mathrm{C}$.

These results go with other recently published study, which suggests that the combination of vegetation and green roofs can reduce the temperature from around $295 \mathrm{~K}$ to $294.20 \mathrm{~K}$ [51]. Additionally, M. Burse and J. Carol found that combining green-roofs with street-level vegetation can reduce the air temperature uniform ally with a maximum of $2.4 \mathrm{~K}$. [52]. However, previous studies such [52], [53] have found $1-2^{\circ} \mathrm{C}$ temperature reduction with green-roofs.

However, the ambient air temperature was not changed in the scenario "(d)" $25 \%$ of green-roof; it suggests that green-goofs/green-infrastructures ratio was not sufficient to reduce air temperature and moderates the microclimate. Where the maximum and minimum temperature has not changed with $33.68^{\circ} \mathrm{C}$ and $31.69^{\circ} \mathrm{C}$ respectively.

These results suggest that air temperature regulation cannot be achieved before setting up 50\% of green-roofs as a minimum ratio.

\section{DISCUSSION AND CONCLUSION}

We have demonstrated in this paper the impact of green roofs on UHI mitigation, and we defined a decision model that helps calculating the best green-roof/green-infrastructure ratio. The sustainability of this strategy of green-roofs is more durable, and produces less environmental impact during its life cycle. Constantine, like many other semi-arid regions around the world, has encountered severe challenges, due to the high population growth rate and the need of new resources, especially water resources. Consequently, the adopted 
sustainable practices must insure reasonable effects on climate change.

The definition of the best green-roof/green-infrastructure

can reduce the costs of setting up green areas. Especially in regions where sustainable economics still in its early stages. The feasibility of the mentioned UHI mitigation strategies (e.g., the irrigation of green roofs by treated waste water) should be considered.

As shown in the previous section, the scenario of $50 \%$ of green-roof gives the best green-roof/green-infrastructure ratio, which mean that $4971.7 \mathrm{~m}^{2}$ of green roof can reduce $1.24^{\circ} \mathrm{C}$ in average during day-time. Urban planners and city administrations can use the decision model to increase urban green planning when implementing UGI measures into practice, while using wise budgets.

In addition, the results of our study indicate not only the impact of green-roofs on UHI, but also the effect of large-scale green-roof installation on the liveable areas in sustainable cities.

The simulation results show that when we apply green-roofs on a city scale, they may reduce an average ambient temperature of 0.3 and $3 \mathrm{~K}$ [54]. We would note here that, due to the limitation of ENVI-met, it is impossible to make the simulation for a whole city at once, because the maximum number of grid cells of the model is quite limited [55]. This limitation can be avoided by running simulation recursively on the city areas.

Coupling meso-micro-scale model could be useful to investigate the potential cooling effect of GR strategies on different climate-change scales [55]. This can help reducing the UHI in a city, which in its turn can reduce the energy consumption. Akbari found that peak energy demand in the USA rises by 2-4\% for every $1 \mathrm{~K}$ increase in maximum air temperature [56]; this means that if we could reduce the maximum temperature by just $1-2 \mathrm{~K}$ (by cooling residential areas with the green-roof/green-infrastructure), then we can reduce energy consumption by about $2.5-6$ percent. Finally, and in addition to all the benefits of conventional green areas, green-roofs help saving energy, can lead to better urban living conditions, and fight global warming.

\section{REFERENCES}

[1] L. Howard, "The climate of London: Deduced from meteorological observations, made at different places in the neighborhood of the metropolis," vol. 1, 1818.

[2] T. R. Oke, Boundary Layer Climates, New York: Routledge, 2002.

[3] L. Bernstein, P. Bosch, O. Canziani, Z. Chen, R. Christ, O. Davidson, W. Hare et al., "Climate change 2007: Synthesis report: An assessment of the intergovernmental panel on climate change," 2008.

[4] H. Taha, "Urban climates and heat islands: Albedo, evapotranspiration, and anthropogenic heat," Energy and Buildings, vol. 25, no. 2, pp. 99-103, 1997.

[5] M. R. Emmanuel, An Urban Approach to Climate-Sensitive Design: Strategies for the Tropics, Taylor \& Francis SponPress, London, UK, 2005.

[6] W. Y. Fung, K. S. Lam, W. T Hung, S. W. Pang, and Y. L. Lee, "Impact of urban temperature on energy consumption of Hong Kong," Energy, vol. 31, no. 14, pp. 2623-2637, 2006.

[7] M. Kolokotroni, Y. Zhang, and R. Watkins, " The London heat island and building cooling design," Solar Energy, vol. 81, no. 1, pp. 102-110, 2007.

[8] Y. Hirano and T. Fujita, "Evaluation of the impact of the urban heat island on residential and commercial energy consumption in Tokyo," Energy, vol. 37, no. 1, pp. 371-383, 2012.
[9] F. Salamanca, M. Georgescu, A. Mahalov, M. Moustaoui, M. Wang, and B. M. Svoma, "Assessing summertime urban air conditioning consumption in a semiarid environment," Environmental Research Letters, vol. 8, no. 3, p. 034022, 2013.

[10] S. Konopacki and H. Akbari, "Energy savings for heat-island reduction strategies in Chicago and Houston (including updates for Baton Rouge, Sacramento, and Salt Lake City)," Lawrence Berkeley National Laboratory, University California, February 2002.

[11] S. Hassid, M. Santamouris, N. Papanikolaou, A. Linardi, N. Klitsikas, C. Georgakis, and D. N. Assimakopoulos, "The effect of the Athens heat island on air conditioning load," Energy and Buildings, vol. 32, no. 2, pp. 131-141, 2000.

[12] C. Huizenga, S. Abbaszadeh, L. Zagreus, and E. A. Arens, “ Air quality and thermal comfort in office buildings: results of a large indoor environmental quality survey," in Proc. Healthy Buildings, no. 3, 2006.

[13] C. Sarrat, A. Lemonsu, V. Masson, and D. Guedalia, "Impact of urban heat island on regional atmospheric pollution," Atmospheric Environment, vol. 40, no. 10, pp. 1743-1758, 2006

[14] E. Stathopoulou, G. Mihalakakou, M. Santamouris, and H. S. Bagiorgas, "On the impact of temperature on tropospheric ozone concentration levels in urban environments," Journal of Earth System Science, vol. 117, no. 3, pp. 227-236, 2008.

[15] W. W. Nazaroff, "Exploring the consequences of climate change for indoor air quality," Courtesy of the National Academies Press, Washington, DC. Environmental Research Letters, vol. 8, no. 1, p. 015022, 2013.

[16] K. Pantavou, G. Theoharatos, A. Mavrakis, and M. Santamouris, "Evaluating thermal comfort conditions and health responses during an extremely hot summer in Athens," Building and Environment, vol. 46, no. 2, pp. 339-344, 2011

[17] A. K. Mishra and M. Ramgopal, "Field studies on human thermal comfort - An overview," Building and Environment, vol. 64, pp. 94-106, 2013.

[18] J. A. Patz, D. Campbell-Lendrum, T. Holloway, and J. A Foley, "Impact of regional climate change on human health," Nature, vol. 438, no. 7066, pp. 310-317, 2005

[19] D. Li and E. Bou-Zeid, "Synergistic interactions between urban heat islands and heat waves: The impact in cities is larger than the sum of its parts," Journal of Applied Meteorology and Climatology, vol. 52, no. 9, pp. 2051-2064, 2013.

[20] W. P. Lowry, "Empirical estimation of urban effects on climate: A problem analysis," Journal of Applied Meteorology, vol. 16, no. 2, pp. 129-135, 1977.

[21] S. N. Goward, "Thermal behavior of urban landscapes and the urban heat island," Physical Geography, vol. 2, no. 1, pp. 19-33, 1981.

[22] J. Nichol, "Remote sensing of urban heat islands by day and night," Photogrammetric Engineering \& Remote Sensing, vol. 71, no. 5, pp. 613-621, 2005.

[23] H. Kusaka, F.Chen, and M. Tewari, and H. Hirakuchi, "Impact of using the urban canopy model on the simulation of the heat island," in Proc. the WRF/MM5 Users' Workshop, Boulder, USA, 28 June 2005.

[24] USEPA. Reducing urban heat islands: Compendium of strategies, heat island reduction activities. [Online]. Available: https://www.epa.gov/sites/production/files/2014-06/documents/activit iescompendium.pdf

[25] C. Folke, S. Carpenter, T. Elmqvist, L. Gunderson, C. S. Holling, and B. Walker, "Resilience and sustainable development: building adaptive capacity in a world of transformations," AMBIO: A Journal of the Human Environment, vol. 31, no. 5, pp. 437-440, 2002.

[26] B. Smit, B. and O. Pilifosova, "Adaptation to climate change in the context of sustainable development and equity," Sustainable Development, vol. 8, no. 9, pp. 879-912, 2003.

[27] S. E. Gill, J. F. Handley, A. R. Ennos, and S. Pauleit, "Adapting cities for climate change: the role of the green infrastructure," Built Environment, vol. 33, no. 1, pp. 115-133, 2007.

[28] Y. Wang, F. Bakker, R. Groot, and H. Wörtche, "Effect of ecosystem services provided by urban green infrastructure on indoor environment: A literature review," Building and Environment, vol. 77, pp. 88-100, 2014.

[29] X. Yang, L. Zhao, M. Bruse, and Q. Meng, “An integrated simulation method for building energy performance assessment in urban environments," Energy and Buildings, vol. 54, pp. 243-251, 2012.

[30] M. Fahmy and S. Sharples, "Urban form, thermal comfort and building CO2 emissions - A numerical analysis in Cairo," Building Services Engineering Research and Technology, vol. 32, no. 1, pp. 73-84, 2011. 
[31] H. Takebayashi and M. Moriyama, "Surface heat budget on green roof and high reflection roof for mitigation of urban heat island," Building and Environment, vol. 42, no. 8, pp. 2971-2979, 2007.

[32] H. Akbari, L. S. Rose, and H. Taha, "Analyzing the land cover of an urban environment using high-resolution orthophotos," Landscape and Urban Planning, vol. 63, no. 1, pp. 1-14, 2003.

[33] D. J. Sailor, T. B. Elley, and M. Gibson, "Exploring the building energy impacts of green roof design decisions - A modeling study of buildings in four distinct climates," Journal of Building Physics, September 2011 .

[34] U. Berardi and A. G. Hoseini, "State-of-the-art analysis of the environmental benefits of green roofs," Applied Energy, vol. 115, pp. 411-428, 2014.

[35] J. J. Baik, K. H. Kwak, S. B. Park, and Y. H. Ryu, "Effects of building roof greening on air quality in street canyons," Atmospheric Environment, vol. 61, pp. 48-55, 2012.

[36] J. C. Berndtsson, "Green roof performance towards management of runoff water quantity and quality: A review," Ecological Engineering, vol. 36 , no. 4, pp. 351-360, 2010.

[37] I. Jaffal, S. E. Ouldboukhitine, and R. Belarbi, "A comprehensive study of the impact of green roofs on building energy performance," Renewable Energy, vol. 43, pp. 157-164, 2012.

[38] D. B. Rowe, "Green roofs as a means of pollution abatement," Environmental Pollution, vol. 159, no. 8, pp. 2100-2110, 2011.

[39] E. Oberndorfer, J. Lundholm, B. Bass, R. R. Coffman, H. Doshi, N. Dunnett et al., "Green roofs as urban ecosystems: ecological structures, functions, and services," BioScience, vol. 57, no. 10, pp. 823-833, 2007.

[40] A. M. Coutts, E. Daly, J. Beringer, and N. J. Tapper, "Assessing practical measures to reduce urban heat: Green and cool roofs," Building and Environment, vol. 70, pp. 266-276, 2013.

[41] B. Dvorak and A. Volder, "Rooftop temperature reduction from unirrigated modular green roofs in south-central Texas," Urban Forestry \& Urban Greening, vol. 12, no. 1, pp. 28-35, 2013.

[42] C. Farrell, R. E. Mitchell, C. Szota, J. P. Rayner, and N. S. G. Williams, "Green roofs for hot and dry climates: Interacting effects of plant water use, succulence and substrate," Ecological Engineering, vol. 49, pp. 270-276, 2012

[43] R. Fioretti, A. Palla, L. G. Lanza, and P. Principi, "Green roof energy and water related performance in the Mediterranean climate," Building and Environment, vol. 45, no. 8, pp. 1890-1904, 2010.

[44] B. S. Lin, C. C. Yu, A. T. Su, and Y. J. Lin, "Impact of climatic conditions on the thermal effectiveness of an extensive green roof," Building and Environment, vol. 67, pp. 26-33, 2013.

[45] F. Olivieri, C. Perna, M. D’Orazio, L. Olivieri, and J. Neila, "Experimental measurements and numerical model for the summer performance assessment of extensive green roofs in a Mediterranean coastal climate," Energy and Buildings, vol. 63, pp. 1-14, 2013.

[46] S. E. Ouldboukhitine, R. Belarbi, and R. Djedjig, "Characterization of green roof components: measurements of thermal and hydrological properties," Building and Environment, vol. 56, pp. 78-85, 2012.

[47] P. M. Klein and R. Coffman, "Establishment and performance of an experimental green roof under extreme climatic conditions," Science of the Total Environment, vol. 512, pp. 82-93, 2015.
[48] M. D'orazio, C. Perna, and E. Giuseppe, "Green roof yearly performance: a case study in a highly insulated building under temperate climate," Energy and Buildings, vol. 55, pp. 439-451, 2012.

[49] A. Matzarakis, M. Zygmuntowski, E. Koch, and E. Rudel, "Mapping the thermal bioclimate of Austria for health and recreation tourism," Advances in Tourism Climatology, 2nd International Workshop Climate, Tourism and Recreation, no.12, pp.10-18, 2004.

[50] M. Bruse and H. Fleer, "Simulating surface-plant-air interactions inside urban environments with a three dimensional numerical model," Environmental Modelling \& Software, vol. 13, no. 3, pp. 373-384, 1998.

[51] S. Sodoudi, P. Shahmohamadi, K. Vollack, U. Cubasch, and A. I Che-Ani, "Mitigating the urban heat island effect in megacity Tehran," Advances in Meteorology, vol. 2014, no. 547974, p. 19, 2014.

[52] M. Bruse and C. J. Skinner, "Rooftop greening and local climate: A case study in Melbourne," in Proc. the 15th International Congress of Biometeorology \& International Conference on Urban Climatology Urban Climatology, November1999.

[53] L. L. Peng and C. Y. Jim, "Green-roof effects on neighborhood microclimate and human thermal sensation," Energies, vol. 6, no. 2, pp. 598-618, 2013.

[54] M. Santamouris, "Cooling the cities-a review of reflective and green roof mitigation technologies to fight heat island and improve comfort in urban environments," Solar Energy, vol. 103, pp. 682-703, 2014.

[55] S. Huttner, M. Bruse, P. Dostal, and A. Katzschner, "Strategies for mitigating thermal heat stress in Central European cities: The project KLIMES," in Proc. the 7th International Conference on Urban Climate, vol. 29, June 2009.

[56] S. E. Asgharpour, H. Zanjani, and G. Taleghani, "Impact of urbanization on population changes in metropolitan area of Tehran, Iran," in Proc. the 3rd International Geography Symposium, p. 21, 2013.

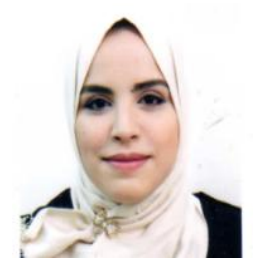

Sara Sahnoune a graduate student researcher at the Laboratory of Bioclimatic Architecture and Environment, University Constantine 3, Algeria. She has earned her architectural engeneering diplomae in 2014 from the University of Constantine 3, Algeria.

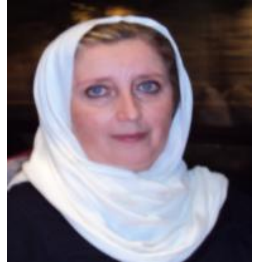

Nassira Benhassine is urban architecte professsor and one member with Laboratory Bioclimatic Architecture and Environment, Faculty of Architecture and Urban Planning, University of Constantine 3, Algeria.

She received her architectural eng. diplomae in 1988, graduated urbaning in 1999 and the ph.D in 2012 from the University of Constantine. Her research interests are related to the environment, suistainable development, urban project, suistanable urban planing, vegetation and landscape. 